\title{
PERTUMBUHAN KEDELAI (Glycine max [L.] Merrill) VARIETAS ANJASMORO DENGAN PEMBERIAN BIOURIN KAMBING (Capra aegagrus hircus)
}

\author{
Abd. Hamid $^{1}$ *, Riza Linda ${ }^{1}$, Mukarlina ${ }^{1}$ \\ ${ }^{1}$ Program Studi Biologi, Fakultas Matematika \& Ilmu Pengetahuan Alam, Universitas Tanjungpura \\ Jl. Prof. Dr. H. Hadari Nawawi, Pontianak, Kalimantan Barat, 78124, Indonesia \\ *Email: ikhwanhamed1994@gmail.com
}

\begin{abstract}
Soybean (Glycine $\max$ [L.] Merrill) Anjasmoro variety is one of the superior soybean varieties widely cultivated in West Kalimantan. The growth of soybean can be increased by applying liquid organic fertilizer namely goat biourine. The purpose of this study was to determine the goat biourine quality and the effect of the application of goat biourine on the growth of Anjasmoro variety soybean plants. This study uses a Completely Randomized Design (CRD) consisting of five treatments, namely without biourine/control, 100 $\mathrm{mL} / \mathrm{L}$ biourine, $200 \mathrm{~mL} / \mathrm{L}$ biourine, 300 biourine $\mathrm{mL} / \mathrm{L}$ and $400 \mathrm{~mL} / \mathrm{L}$ biourine. Each treatment was repeated 5 times to obtain 25 experimental units. The analysis of goat biourine showed the value of $\mathrm{C}$ Organic $2.03 \%, \mathrm{pH} 4.83, \mathrm{~N} 0.72 \%, \mathrm{P} 0.004 \%$ and $\mathrm{K} 0.234 \%$. The results showed that apply of goat biourine had a significant effect on plant height, number of leaves, shoot wet of weight, shoot dry of weight, number of branches, number of root nodules and the number of effective root nodules, but it had not a significant effect on root wet of weight and root dry of weight.
\end{abstract}

Keywords: Goat biourine, growth, soybean (Glycine max) Anjasmoro variety

\section{PENDAHULUAN}

Kedelai (Glycine $\max$ [L.] Merrill) merupakan tanaman pangan yang dimanfaatkan sebagai bahan pangan sehari-hari, bahan baku industri dan pakan ternak. Kedelai umumnya dikonsumsi dalam bentuk pangan olahan seperti tahu, tempe, kecap, tauco, susu kedelai dan bentuk olahan lainnya. Kandungan gizi kedelai cukup besar seperti protein sebesar $35 \%$, lemak $18 \%$ dan karbohidarat 35\% (Winarsi, 2010). Peluang usaha dari industri pangan berbahan dasar kedelai cukup besar bagi usaha agribisnis kedelai seperti usaha tani, pengolahan dan pemasaran (Swastika et al., 2007). Hal ini menyebabkan budidaya kedelai menjadi sangat penting.

Kedelai varietas Anjasmoro merupakan salah satu kedelai varietas unggul yang banyak diminati oleh masyarakat karena memiliki ukuran biji yang besar dan produktivitasnya mencapai 2,5 ton/ha. Varietas ini paling sering digunakan sebagai bahan baku pembuat tahu, tempe, kecap, tauco, susu kedelai dan berbagai olahan (Sudaryanto \& Swastika, 2007).

Luas lahan gambut di Kalimantan Barat sebesar 1,72 juta ha (CKPP, 2008). Luas lahan gambut di Kalimantan Barat dapat dimanfaatkan sebagai lahan pertanian yaitu melalui kegiatan ekstensifikasi pertanian dan pemanfaatan lahan- lahan marginal, namun pengelolaan lahan gambut sebagai lahan pertanian masih kurang optimal, karena terkendala oleh kondisi lahan gambut yaitu $\mathrm{pH}$ tanah asam, kapasitas tukar kation yang rendah, kejenuhan basa yang rendah, kandungan unsur hara makro dan mikro tersedia (seperti $\mathrm{N}, \mathrm{P}, \mathrm{K}, \mathrm{Cu}, \mathrm{Zn}, \mathrm{Mn}$, $\mathrm{Ca}, \mathrm{Mg}$ ) yang rendah (Agus \& Subiksa, 2008).

Budidaya kedelai di lahan gambut tidak menunjukkan pertumbuhan yang baik. Penggunaan varietas unggul serta pengolahan lahan gambut yang baik dapat menjadi solusi terhadap permasalahan budidaya kedelai. Pertumbuhan dan hasil benih ditentukan oleh faktor varietas yang digunakan, lingkungan dan pemeliharaan (Purwanti, 2011).

Kendala budidaya kedelai pada lahan gambut dapat diatasi dengan beberapa cara diantaranya dengan pemupukan. Penggunaan pupuk anorganik dapat meningkatkan pertumbuhan dan produksi tanaman, namun pemakaian secara terus menerus dapat menyebabkan berkurangnya kesuburan tanah (Jumrawati, 2008). Penggunaan pupuk anorganik dalam jangka panjang juga dapat menyebabkan kemunduran sifat-sifat fisik, kimia dan biologi tanah (Sutedjo, 2008). Pemberian pupuk organik dapat menjadi alternatif dalam proses pemupukan karena pupuk organik memiliki beberapa kelebihan yaitu dapat menggemburkan tanah, memacu pertumbuhan mikoorganisme tanah dan membantu transportasi unsur hara tanah 
ke dalam akar tanaman. Penggunaan limbah peternakan dapat diman-faatkan sebagai pupuk organik (Suwahyono, 2011).

Limbah peternakan seperti urin kambing dapat dimanfaatkan sebagai pupuk organik cair (POC) atau biasa disebut biourin. Biourin kambing memiliki kelebihan-kelebihan yaitu kandungan unsur hara $\mathrm{N}$ dan $\mathrm{K}$ yang tinggi (kadar nitrogen (N) sebesar $1,35 \%$ dan kalium (K) sebesar $2,10 \%$ ), kandungan posfor (P) $0,13 \%$ dan mudah diserap oleh tanaman (Abdullah et al., 2011). Kandungan hara biourin kambing lebih tinggi dibandingkan biourin sapi dan biourin kelinci terutama kandungan nirogen $(\mathrm{N})$ dan $(\mathrm{K})$. Urin kambing juga mengandung hormon alami golongan auksin, giberellin dan sitokinin (Tampubolon, 2012; Alvi et al., 2018).

Hasil penelitian Sarah et al., (2016), menunjukkan bahwa pemberian biourin kambing dengan konsentrasi $100 \mathrm{~mL} / \mathrm{L}$ dan $200 \mathrm{~mL} / \mathrm{L}$ dapat meningkatkan jumlah daun dan berat kering tanaman lada (Piper nigrum L.). Pemberian pupuk organik cair (POC) $120 \mathrm{~mL} / \mathrm{L}$ dapat meningkatkan tinggi tanaman, bobot kering tajuk tanaman kedelai (Rahman et al., 2017). Berdasarkan hal tersebut, perlu dilakukan penelitian penggunaan limbah urin kambing sebagai pupuk organik cair terhadap pertumbuhan kedelai varietas Anjasmoro.

\section{BAHAN DAN METODE}

\section{Waktu dan Tempat Penelitian}

Penelitian ini dilakukan dari bulan Januari sampai dengan April 2019. Analisis tanah, kebutuhan kapur dan urin kambing hasil fermentasi dilakukan di Laboratorium Kimia dan Kesuburan Tanah, Jurusan, Fakultas Pertanian Universitas Tanjungpura Pontianak. Penanaman, pemupukan, pengamatan dan pengukuran tanaman kedelai dilakukan di Jurusan Biologi Fakultas Matematika dan Ilmu Pengetahuan Alam Universitas Tanjungpura, Pontianak, Kalimantan Barat.

\section{Rancangan Penelitian}

Penelitian ini menggunakan rancangan acak lengkap (RAL) yang terdiri atas 5 taraf perlakuan dan 5 ulangan, sehingga diperoleh 25 unit percobaan, yaitu P0 (kontrol), P1 (100 mL/L), P2 (200 mL/L), P3 (300 mL/L) dan P4 (400 mL/L).

\section{Cara Kerja}

\section{Persiapan Media Tanam}

Media tanam yang digunakan adalah tanah gambut yang diambil pada kedalaman $0-20 \mathrm{~cm}$.
Tanah dikeringanginkan dan diayak menggunakan ayakan berdiameter $5 \mathrm{~mm}$ supaya tanah terpisah dari partikel batu maupun ranting. Tanah hasil ayakan sebanyak $3 \mathrm{~kg}$ dicampur dengan kapur dolomit sebanyak 194,83 g/polybag berdasarkan kebutuhan kapur/polybag dan dimasukkan kedalam polybag dan diinkubasi selama 2 minggu hingga $\mathrm{pH}$ mendekati netral $( \pm 7)$ (Agil et al., 2019).

\section{Pembuatan Biourin}

Urin kambing sebanyak 1,6 L urin difermentasi dengan ditambahkan $16 \mathrm{~mL}$ EM4 dan dimasukkan air gula sebanyak $120 \mathrm{~mL}$, diaduk hingga rata, kemudian wadah botol ditutup rapat dan diinkubasi selama 14 hari (Huda, 2013).

\section{Pemilihan Biji Kedelai dan Penanaman}

Biji kedelai yang dipilih memiliki ciri-ciri yaitu permukaan kulit bersih, cerah, tidak keriput dan memiliki ukuran yang sama. Penanaman dilakukan dengan menebar biji kedelai sebanyak tiga biji per polybag. Hasil semaian yang pertumbuhannya baik dipilih 1 tanaman sebagai tanaman uji dan sisanya dicabut. Pemilihan tanaman uji dilakukan 14 hari setelah tanam (HST). Tanaman yang dipilih sebagai tanaman uji yaitu tinggi tanaman sekitar $11 \mathrm{~cm}$ dan memiliki 4 sampai 5 helai daun.

\section{Aplikasi Biourin}

Urin kambing hasil fermentasi diberikan berdasarkan perlakuan yang telah ditentukan dalam rancangan penelitian. Biourin kambing diberikan pada umur 14, 21, 28 dan 35 hst (hari setelah tanam) dengan cara melarutkan biourin kambing sesuai perlakuan dalam 1 liter air (Tamba et al., 2017). Pemberian biourin kambing diberikan dengan dosis $20 \mathrm{~mL} /$ tanaman dengan cara disemprotkan di bagian abaksial daun (Rizki et al., 2014).

\section{Pemeliharaan Tanaman}

Pemeliharaan tanaman terdiri dari penyiraman dan penyiangan gulma. Penyiraman dilakukan 2 kali sehari pada waktu pagi dan sore hari. Penyiraman pagi sekitar pukul 07.00 - 08.00 WIB dan sore sekitar 16.00 - 17.00 WIB. Penyiangan gulma dilakukan secara manual dengan mencabut gulma yang ada di sekitar tanaman uji.

\section{Variabel Pengamatan}

\section{Uji Kualitas Sifat Fisik dan Kimia Biourin Kambing}

Biourin kambing yang telah difermentasi diuji kualitasnya berdasarkan sifat fisik, yaitu: aroma dan warna dan Sifat kimia, yaitu: C-Organik, $\mathrm{pH}$ 
dan kandungan hara makro seperti $\mathrm{N}, \mathrm{P}, \mathrm{K}$. Metode yang digunakan untuk analisis N-total adalah Kjeldhal's, fosfor dan kalium dengan metode ekstraksi $\mathrm{H}_{2} \mathrm{SO}_{4}+\mathrm{H}_{2} \mathrm{O}_{2}$, pengukuran $\mathrm{pH}$ dilakukan dengan meggunakan alat $\mathrm{pH}$ meter dan pengukuran C-organik dengan metode Walkey and Black.

\section{Parameter Pertumbuhan}

Parameter pertumbuhan diukur setelah tanaman berumur 42 hst (hari setelah tanam). Parameter pertumbuhan yang diukur yaitu tinggi tanaman (cm), jumlah daun (helai), berat basah tajuk, berat basah akar tanaman $(\mathrm{g})$, berat kering tajuk, berat kering akar tanaman (g), jumlah cabang, jumlah bintil akar dan jumlah bintil akar efektif (g).

\section{Parameter Lingkungan}

Pengamatan parameter lingkungan meliputi suhu $\left({ }^{\circ} \mathrm{C}\right)$ dan kelembapan udara $(\%)$.

\section{Analisis Data}

Data hasil pengamatan pertumbuhan dianalisis menggunakan Analysis of Variance (ANOVA) menggunakan SPSS 18. Hasil ANOVA yang menunjukkan beda nyata maka dilanjutkan dengan uji Duncan pada taraf 5\% (Hanafiah, 2010).

\section{HASIL DAN PEMBAHASAN}

\section{Hasil}

Kualitas biourin kambing diuji berdasarkan sifat fisik dan kimia. Sifat fisik yang diamati meliputi warna dan aroma. Biourin kambing mengalami perubahan warna setelah difermentasi selama 14 hari dari warna kuning bening menjadi kecoklatan dengan aroma alkohol atau khas tapai.

Hasil analisis biourin kambing menunjukkan bahwa kandungan $\mathrm{C}$-Organik tergolong rendah jika dibandingkan dengan standar C-Organik pada peraturan menteri pertanian (Permentan No.28/SR.130/2009). Nilai $\mathrm{pH}$ biourin kambing 4,83 memenuhi standar peraturan menteri pertanian (Permentan No.28/SR.130/2009) yaitu berada pa- da kisaran 4-8. Kadar hara N, P, K biourin kambing sesuai dengan kadar hara pada peraturan menteri pertanian (Permentan No. 28/SR.130/2009) yaitu kurang dari 2 (Tabel 1).

Tabel 1. Analisis Biourin Kambing

\begin{tabular}{cccc}
\hline Parameter & Satuan & $\begin{array}{c}\text { Biourin } \\
\text { Kambing }\end{array}$ & $\begin{array}{c}\text { Permentan } \\
2009\end{array}$ \\
\hline C-Organik & $\%$ & 2,03 & $>4$ \\
pH & & 4,83 & $4-8$ \\
Nitrogen & $\%$ & 0,72 & $<2$ \\
Fosfor & $\%$ & 0,004 & $<2$ \\
Kalium & $\%$ & 0,234 & $<2$ \\
\hline
\end{tabular}

Analysis of variance (ANOVA) digunakan untuk mengetahui pengaruh biourin kambing terhadap pertumbuhan tanaman kedelai pada lima perlakuan yaitu P0 (kontrol), P1 (100 mL/L), P2 (200 $\mathrm{mL} / \mathrm{L})$, P3 $(300 \mathrm{~mL} / \mathrm{L})$ dan P4 $(400 \mathrm{~mL} / \mathrm{L})$. Hasil uji statistik menunjukkan pemberian biourin kambing berpengaruh nyata terhadap tinggi tanaman $\left(\mathrm{F}_{4,20}=4,969, p=0,006\right.$; ANOVA $)$, jumlah daun $\left(\mathrm{F}_{4,20}=3,619, p=0,022\right.$; ANOVA $)$, berat basah tajuk $\left(\mathrm{F}_{4,20}=3,505, p=0,025\right.$; ANOVA $)$, berat kering tajuk $\left(\mathrm{F}_{4,20}=10,623, p=0,000\right.$; ANOVA), jumlah cabang $\left(\mathrm{F}_{4,20}=3,097, p=0,039\right.$; ANOVA), jumlah bintil akar $\left(\mathrm{F}_{4,20}=5,107, p=\right.$ 0,005; ANOVA) dan jumlah bintil akar efektif $\left(\mathrm{F}_{4,20}=5,121, p=0,005\right.$; ANOVA $)$, tetapi tidak berbeda nyata terhadap berat basah akar $\left(\mathrm{F}_{4,20}=\right.$ $1,095, p=0,386$; ANOVA) dan berat kering akar $\left(\mathrm{F}_{4,20}=1,511, p=0,237\right.$; ANOVA $)$.

Hasil uji lanjut rerata tinggi tanaman, jumlah daun kedelai menunjukkan bahwa semua perlakuan konsentrasi biourin yaitu P1 (100 mL/L), P2 (200 $\mathrm{mL} / \mathrm{L})$, P3 $(300 \mathrm{~mL} / \mathrm{L})$ dan $\mathrm{P} 4(400 \mathrm{~mL} / \mathrm{L})$, berbeda nyata dengan kontrol (P0), tetapi tidak berbeda nyata antar perlakuan P1, P2, P3 dan P4. Hasil uji lanjut rerata berat basah tajuk tanaman kedelai menunjukkan bahwa semua perlakuan konsentrasi biourin yaitu P1 (100 mL/L), P2 (200 $\mathrm{mL} / \mathrm{L})$, P3 (300 mL/L) dan P4 (400 mL/L), berbeda nyata dengan kontrol (P0). Perlakuan P0 tidak berbeda nyata dengan perlakuan P4 (Tabel 2).

Tabel 2. Pengaruh Pemberian Biourin Kambing terhadap Rerata Tinggi Tanaman, Jumlah Daun, Berat Basah Tajuk dan Berat Basah Akar Tanaman Kedelai 42 HST (Hari Setelah Tanam)

\begin{tabular}{ccccc}
\hline Perlakuan & $\begin{array}{c}\text { Tinggi } \\
\text { Tanaman } \\
(\mathrm{cm})\end{array}$ & $\begin{array}{c}\text { Jumlah Daun } \\
\text { (helai) }\end{array}$ & Berat Basah Tajuk (g) & Berat Basah Akar (g) \\
\hline P0 & $56,36 \pm 5,86^{\mathrm{a}}$ & $24,20 \pm 2,28^{\mathrm{a}}$ & $56,02 \pm 5,67^{\mathrm{a}}$ & $31,12 \pm 8,41$ \\
P1 & $\mathbf{6 7 , 3 0}^{\mathbf{3}} \mathbf{3 , 4 5}$ & $\mathbf{2 7 , 6 0} \pm \mathbf{1 , 6 7}$ & $\mathbf{6 6 , 9 0 \pm 9 , 2 3}$ & $37,64 \pm 8,93$ \\
P2 & $69,22 \pm 5,56^{\mathrm{b}}$ & $29,40 \pm 2,79^{\mathrm{b}}$ & $68,96 \pm 6,47^{\mathrm{b}}$ & $42,28 \pm 11,92$ \\
P3 & $70,38 \pm 6,35^{\mathrm{b}}$ & $27,80 \pm 1,92^{\mathrm{b}}$ & $72,18 \pm 10,04^{\mathrm{b}}$ & $40,20 \pm 11,62$ \\
P4 & $65,82 \pm 6,19^{\mathrm{b}}$ & $27,80 \pm 2,38^{\mathrm{b}}$ & $65,05 \pm 1,99^{\text {ab }}$ & $43,58 \pm 11,28$ \\
\hline
\end{tabular}

Keterangan:Angka-angka yang diikuti huruf yang sama pada baris atau kolom yang sama tidak berbeda nyata pada uji Duncan taraf 5\%. P0 (kontrol), P1 (100 mL/L), P2 (200 mL/L), P3 (300 mL/L), P4 (400 mL/L) 
Tabel 3. Pengaruh Pemberian Biourin Kambing terhadap Rerata Berat Kering Tajuk, Berat Kering Akar, Jumlah Cabang, Jumlah Bintil Akar dan Jumlah Bintil Akar Efektif Tanaman Kedelai 42 HST (Hari Setelah Tanam)

\begin{tabular}{ccclll}
\hline Perlakuan & $\begin{array}{c}\text { Berat Kering } \\
\text { Tajuk }(\mathrm{g})\end{array}$ & $\begin{array}{c}\text { Berat Kering } \\
\text { Akar }(\mathrm{g})\end{array}$ & $\begin{array}{l}\text { Jumlah } \\
\text { Cabang }\end{array}$ & Jumlah Bintil Akar & $\begin{array}{l}\text { Jumlah Bintil Akar } \\
\text { Efektif }\end{array}$ \\
\hline P0 & $13,93 \pm 1,91^{\mathrm{a}}$ & $8,49 \pm 2,37$ & $5,8 \pm 0,83^{\mathrm{a}}$ & $37 \pm 12,10^{\mathrm{a}}$ & $28,80 \pm 8,72^{\mathrm{a}}$ \\
P1 & $\mathbf{1 8 , 8 3}^{\mathrm{a}} \mathbf{1 , 6 2}^{\mathbf{b}}$ & $7,99 \pm 2,50$ & $\mathbf{6 , 8}^{\mathrm{b}} \mathbf{0 , 8 3}^{\text {ab }}$ & $\mathbf{5 8 , 6 0} \pm \mathbf{1 0 , 5 0}^{\mathbf{b}}$ & $\mathbf{5 3 , 2 0} \pm \mathbf{9 , 8 8}^{\mathbf{b}}$ \\
P2 & $18,55 \pm 1,59^{\mathrm{b}}$ & $7,64 \pm 2,88$ & $8,4 \pm 1,14^{\mathrm{b}}$ & $67 \pm 8,63^{\mathrm{b}}$ & $59 \pm 12,22^{\mathrm{b}}$ \\
P3 & $19,72 \pm 1,57^{\mathrm{b}}$ & $10,42 \pm 3,86$ & $7,4 \pm 1,51^{\mathrm{ab}}$ & $57,60 \pm 15,12^{\mathrm{b}}$ & $50,80 \pm 16,90^{\mathrm{b}}$ \\
P4 & $17,79 \pm 0,77^{\mathrm{b}}$ & $11,11 \pm 2,05$ & $7,2 \pm 1,48^{\mathrm{ab}}$ & $53,60 \pm 6,22^{\mathrm{b}}$ & $47,40 \pm 5,59^{\mathrm{b}}$ \\
\hline
\end{tabular}

Keterangan: Angka-angka yang diikuti huruf yang sama pada baris atau kolom yang sama tidak berbeda nyata pada uji Duncan taraf 5\%. P0 (kontrol), P1 (100 mL/L), P2 (200 mL/L), P3 (300 mL/L), P4 (400 mL/L).

Hasil uji lanjut rerata berat kering tajuk tanaman kedelai menunjukkan bahwa semua perlakuan konsentrasi biourin yaitu P1 (100 mL/L), P2 (200 $\mathrm{mL} / \mathrm{L})$, P3 $(300 \mathrm{~mL} / \mathrm{L})$, dan P4 $(400 \mathrm{~mL} / \mathrm{L})$, berbeda nyata dengan kontrol (P0), tetapi tidak berbeda nyata antar perlakuan P1, P2, P3, dan P4. Hasil uji lanjut rerata jumlah cabang tanaman kedelai menunjukkan bahwa perlakuan konsentrasi biourin kontrol (P0) tidak berbeda nyata dengan P1 (100 mL/L), P3 (300 mL/L), dan P4 (400 $\mathrm{mL} / \mathrm{L})$, tetapi berbeda nyata dengan P2 (200 $\mathrm{mL} / \mathrm{L}$ ). Hasil uji lanjut rerata jumlah bintil akar dan jumlah bintil akar efektif tanaman kedelai menunjukkan bahwa semua perlakuan konsentrasi biourin yaitu P1 $(100 \mathrm{~mL} / \mathrm{L}), \mathrm{P} 2(200 \mathrm{~mL} / \mathrm{L}), \mathrm{P} 3$ $(300 \mathrm{~mL} / \mathrm{L})$, dan P4 $(400 \mathrm{~mL} / \mathrm{L})$, berbeda nyata dengan kontrol (P0), tetapi tidak berbeda nyata antar perlakuan P1, P2, P3, dan P4 (Tabel 3).

\section{Pembahasan}

Urin kambing yang difermentasi selama 14 hari mengalami perubahan warna dan aroma. Perubahan warna yang terlihat yaitu perubahan warna kuning bening menjadi warna kecoklatan, sedangkan aroma khas biourin kambing yaitu perubahan aroma khas urin menjadi beraroma khas tapai. Perubahan warna dan aroma pada urin kambing menunjukkan adanya aktivitas mikroorganisme perombak bahan organik selama proses fermentasi. Keberhasilan pembuatan pupuk organik cair ditandai dengan bau yang khas, warna berubah menjadi coklat dan pupuk yang dihasilkan berwarna kuning kecoklatan (Sundari et al., 2012). Proses fermentasi dalam pembuatan biourin yang berlangsung dalam kondisi anaerob akan menghasilkan gas metan $\left(\mathrm{CH}_{4}\right)$, karbondioksida $\left(\mathrm{CO}_{2}\right)$ dan asam organik (Simamora et al., 2006). Urin kambing setelah difermentasi selama 14 hari sudah dapat digunakan sebagai pupuk organik cair dengan ciri-ciri bau ureum pada urin sudah berkurang atau hilang dan warna urin coklat kehitaman (Kurniadinata, 2008; Jainurti, 2016).

Nilai hasil uji kualitas biourin kambing meliputi unsur hara $\mathrm{N}, \mathrm{P}, \mathrm{K}, \mathrm{C}$-organik dan nilai $\mathrm{pH}$ memenuhi standar peraturan menteri pertanian
(Permentan No.28/SR.130/2009) kecuali nilai Corganik. Kandungan unsur hara nitrogen $(\mathrm{N})$ $(0,72 \%)$ memiliki nilai yang memenuhi standar peraturan menteri pertanian (Permentan No.28/SR.130/2009) $(<2 \%)$ dan memiliki nilai yang tertinggi dibandingkan unsur fosfor (P) $(0,004 \%)$ dan kalium $(\mathrm{K})(0,234 \%)$. Nilai $\mathrm{pH}$ dalam biourin kambing memenuhi standar peraturan menteri pertanian (Permentan No. 28/SR.130/2009) yaitu 4,83. Nilai pH dalam biourin kambing tergolong asam setelah difermentasi 14 hari karena dipengaruhi oleh aktivitas kelompok mikroorganisme dalam proses penguraian bahan organik di dalam biourin kambing. Aktivitas kelompok bakteri seperti bakteri metanogen yang merombak senyawa-senyawa asam organik menjadi senyawa yang lebih sederhana seperti metana, amonia, dan karbondioksida menyebabkan menurunnya nilai pH (Prahesti dan Yulya, 2008 dalam Kurniawan et al., 2017). Hal ini diperkuat oleh Dwidjoseputro (2005) bahwa aktivitas mikroorganisme dalam proses fermentasi akan menguraikan glukosa menjadi etanol dan karbondioksida sehingga derajat keasaman $(\mathrm{pH})$ biourin menurun.

Kandungan C-organik pada biourin kambing sebesar $2,03 \%$ belum memenuhi standar peraturan menteri pertanian (Permentan No. 28/SR.130/2009) (Tabel 1). Hal ini diduga kandungan bahan organik yang rendah pada biourin digunakan sebagai sumber energi bagi mikroorganisme. Hal ini diperkuat oleh pernyataan Nur $e t$ al. (2016) bahwa C-organik yang rendah disebabkan oleh karbon yang digunakan sebagai sumber energi oleh mikroorganisme dan hilang dalam bentuk $\mathrm{CO}_{2}$ mengakibatkan kandungan karbon semakin lama akan berkurang.

Biourin kambing mengandung hara $\mathrm{N}, \mathrm{P}$ dan $\mathrm{K}$ yang sesuai stamdar peraturan menteri pertanian (Permentan No.28/SR.130/2009) (Tabel 1). Kandungan hara dalam biourin kambing berhubungan dengan aktivitas perombakan oleh mikroorganisme pengurai. Kandungan hara pada biourin kambing merupakan hasil dekomposisi bahan organik 
oleh mikroorganisme pengurai menjadi bentuk yang tersedia bagi tanaman (Rangkuti et al., 2017).

Hasil pengamatan terhadap tinggi tanaman dan jumlah daun menunjukkan bahwa pemberian biourin kambing dengan konsentrasi perlakuan $100 \mathrm{ml} / \mathrm{L}$ memberikan hasil terbaik (Tabel 2). Kondisi ini diduga karena di dalam biourin kambing dengan konsentrasi $100 \mathrm{~mL} / \mathrm{L}$ telah terkandung hara yang sesuai untuk pertumbuhan tanaman kedelai. Kandungan hara dan zat pengatur tumbuh dalam biourin kambing dapat menyebabkan meningkatnya pembelahan sel-sel di daerah meristem apikal pucuk dan primordial daun. POC (pupuk oganik cair) yang mengandung unsur hara esensial $\mathrm{N}, \mathrm{P}, \mathrm{K}, \mathrm{Mg}$ dan $\mathrm{Ca}$ akan menyebabkan terpacunya sel maristem dalam pembelahan dan pemanjangan sel pada batang sehingga dengan bertambahnya jumlah sel akan memengaruhi pertambahan tinggi tanaman (Masluki et al., 2017). Hal ini diperkuat oleh Lingga (2010) bahwa unsur N (nitrogen) dalam biourin kambing sangat dibutuhkan tanaman untuk sintesis protein dan asam amino yang dapat mempercepat pembelahan dan pemanjangan sel, sehingga memengaruhi tinggi tanaman.

Pertumbuhan tinggi tanaman kedelai juga dipengaruhi oleh kandungan zat pengatur tumbuh sitokinin dalam biourin kambing. Sitokinin dapat memacu pembelahan sel pada meristem apikal pucuk dan pembentukan organ (Pranata, 2010). Unsur nitrogen $(\mathrm{N})$ berperan dalam pembentukan organ-organ vegetatif (batang, daun dan akar) (Sutedjo, 2002). Jumlah daun berkaitan dengan tinggi tanaman. Semakin tinggi tanaman, maka semakin banyak nodus atau tempat dudukan daun yang terbentuk, sehingga jumlah daun semakin banyak (Prawiranata et al., 1981)

Hasil pengamatan terhadap berat basah tajuk menunjukkan bahwa pemberian biourin kambing dengan konsentrasi $100 \mathrm{~mL} / \mathrm{L}$ memberikan hasil terbaik (Tabel 2). Biourin kambing konsentrasi $100 \mathrm{~mL} / \mathrm{L}$ sudah mengandung unsur-unsur $\mathrm{N}, \mathrm{P}$, $\mathrm{K}$ dan zat pengatur tumbuh yang sesuai untuk pertumbuhan tajuk tanaman kedelai. Meningkatnya berat basah tajuk tanaman disebabkan ketersediaan unsur hara bagi tanaman sangat penting untuk proses pertumbuhan dan adanya zat pengatur tumbuh yang memacu pembelahan dan pembesaran sel (Tiwery, 2014). Pemberian biourin kambing lewat daun juga dapat meningkatkan berat basah tajuk tanaman karena unsur-unsur hara dalam biourin langsung dialirkan melalui pembuluh daun ke bagian tanaman yang membutuhkan unsur hara. Hal ini sesuai dengan pendapat Yanti (2014) bahwa pemberian pupuk melalui daun lebih cepat penyerapan unsur haranya dibandingkan lewat akar. Pemupukan melalui daun dapat menambah ketersediaan hara pada tanaman.

Hasil pengamatan terhadap jumlah cabang memperlihatkan bahwa pemberian biourin kambing dengan konsentrasi perlakuan $100 \mathrm{~mL} / \mathrm{L}$ memberikan hasil terbaik (Tabel 3). Pemberian biourin kambing konsentrasi $100 \mathrm{~mL} / \mathrm{L}$ dapat meningkatkan pertumbuhan jumlah cabang karena adanya kandungan $\mathrm{N}, \mathrm{P}$ dan $\mathrm{K}$ dalam jumlah yang sesuai. Hal ini sesuai dengan pendapat Widodo (2010) bahwa pupuk organik memiliki unsur hara makro dan mikro yang relatif banyak seperti N, P, $\mathrm{K}, \mathrm{Ca}, \mathrm{Mg}$ dan $\mathrm{S}$ serta pemberian pupuk organik cair dapat menyebabkan terpacunya pembelahan dan pembersaran sel pada primordia cabang batang, sehingga jumlah cabang meningkat.

Hasil pengamatan terhadap berat kering tajuk menunjukkan bahwa pemberian biourin kambing dengan konsentrasi $100 \mathrm{~mL} / \mathrm{L}$ memberikan hasil terbaik sejalan dengan jumlah daun (Tabel 2 dan 3). Berat kering tajuk tanaman dipengaruhi oleh jumlah daun. Bertambahnya jumlah daun akan meningkatkan fotosintat. Banyaknya jumlah daun pada tumbuhan dapat meningkatkan laju fotosintesis sehingga mengoptimalkan fotosintat. Penyerapan air dan unsur hara yang optimal juga dapat memengaruhi proses fotosintesis sehingga fotosintat yang dihasilkan tinggi dan menyebabkan berat kering tajuk tanaman juga meningkat (Kester, 1981). Berat kering merupakan akibat dari penimbunan hasil bersih dari asimilasi $\mathrm{CO}_{2}$ sepanjang pertumbuhan yang mencerminkan akumulasi senyawa organik yang berhasil disintesis tanaman dari senyawa anorganik seperti air dan $\mathrm{CO}_{2}$ (Gardner et al., 1991).

Hasil pengamatan terhadap jumlah bintil akar dan jumlah bintil akar efektif menunjukkan bahwa pemberian biourin kambing dengan konsentrasi $100 \mathrm{~mL} / \mathrm{L}$ memberikan hasil terbaik (Tabel 3). Hal ini diduga unsur hara dalam biourin kambing dapat meningkatkan fotosintat dan translokasinya menuju akar yang dimanfaatkan oleh bakteri bintil akar untuk membentuk ATP. Kandungan posfor (P) dan kalium (K) dalam biourin kambing dapat memengaruhi pertumbuhan bintil akar. Unsur $\mathrm{P}$ dalam pupuk organik berperan penting dalam sintesis ATP dan NADPH sebagai suplai energi dalam pembentukan bintil akar (Mulyadi, 2012). Unsur hara kalium juga berperan dalam meningkatkan translokasi hasil fotosintesis ke bagian akar yang digunakan oleh bakteri Rhizobium. 
Pembentukan bintil akar terjadi antara 7-14 hari setelah perkecambahan dengan membentuk rambut-rambut akar, sehingga diperlukan pemupukan pada saat awal pertumbuhan untuk merangsang pertumbuhan bakteri bintil akar (Salisbury \& Ross, 1995). Bintil akar efektif dapat menambat nitrogen di udara dan merombak nitrogen menjadi senyawa asam amino untuk tanaman kacang-kacangan (tanaman legum) (Madigan et al., 2002). Jumlah bintil akar efektif yang lebih banyak mampu meningkatkan penambatan nitrogen yang dapat digunakan dalam sintesis klorofil dan enzim untuk meningkatkan fotosintesis, sehingga pertumbuhan tanaman juga meningkat (Elkan, 1992).

Pemberian biourin kambing tidak menunjukkan pengaruh nyata pada parameter berat basah akar dan berat kering akar tanaman kedelai (Tabel 2 dan 3). Hal ini diduga karena kandungan hara dalam biourin kambing belum mencukupi untuk pertumbuhan akar tanaman kedelai dan translokasi hara lebih banyak ke bagian tajuk. Biomassa suatu tanaman dipengaruhi oleh oleh tingkat kecukupan hara (Harjadi, 1991). Translokasi fotosintat ke akar dalam jumlah yang sedikit juga memengaruhi berat basah akar dan berat kering akar tanaman karena fotosintat lebih banyak dialokasikan untuk organ-organ di atas tanah atau bagian tajuk. Hal ini ditandai dengan nilai berat kering tajuk lebih tinggi dari berat kering akar (Tabel 3).

Pertumbuhan tanaman kedelai pada konsentrasi $400 \mathrm{~mL} / \mathrm{L}$ mengalami penurunan terhadap tinggi tanaman, jumlah cabang, jumlah bintil akar dan jumlah bintil akar efektif (Tabel 2 dan tabel 3). Pemberian biourin kambing dengan konsentrasi $400 \mathrm{~mL} / \mathrm{L}$ diduga menyebabkan kebutuhan unsurunsur hara menjadi berlebihan untuk pertumbuhan tanaman kedelai. Pemberian konsentrasi POC (pupuk organik cair) yang tidak sesuai untuk kebutuhan tanaman akan menyebabkan pertumbuhan menjadi terhambat (Wijaya, 2010).

Pemberian biourin kambing berpengaruh nyata pada 7 variabel pengamatan terhadap pertumbuhan tanaman kedelai varietas Anjasmoro yaitu tinggi tanaman, jumlah daun, berat basah tajuk, berat kering tajuk, jumlah cabang, jumlah bintil akar dan jumlah bintil akar efektif. Konsentrasi $100 \mathrm{ml} / \mathrm{L}$ memberikan pengaruh terbaik pada parameter tinggi tanaman, jumlah daun, berat basah tajuk, berat kering tajuk, jumlah cabang, jumlah bintil akar dan jumlah bintil efektif.

\section{DAFTAR PUSTAKA}

Abdullah, Budhie \& Lubis, 2011, Pengaruh Aplikasi Urin Kambing dan Pupuk Cair Organik Komersial Terhadap Beberapa Parameter Agronomi Pada Tanaman Pakan Indigofera sp., Jurnal Pastura, vol. 1, no. 1, hal. 5-8

Agil, HS, Linda, R \& Rafdinal, 2019, Pengaruh Konsentrasi Biourin Kelinci terhadap Pertumbuhan Vegetatif Bayam Batik (Amaranthus tricolor L. var. Giti Merah), Protobiont, vol. 8, no. 2, hal. 17-23

Agus, F \& Subiksa, IGM, 2008, Lahan Gambut: Potensi Untuk Pertanian dan Aspek Lingkungan, Balai Penelitian Tanah Badan Penelitian dan Pengembangan Pertanian, Bogor

Alvi, B, Ariyanti, M, \& Maxiselly, Y, 2018, Pemanfaatan Beberapa Jenis Urin Ternak Sebagai Pupuk Organik Cair dengan Konsentrasi yang Berbeda pada Tanaman Kelapa Sawi (Elaeis guineensis Jacq.), Jurnal Kultivasi, vol. 17, no. 2, hal. 625

Dwidjoseputro, D, 2005, Dasar-Dasar Mikrobiologi, Penerbit Djambatan, Jakarta

Elkan, GH, 1992, Biological Nitrogen Fixation System in Tropical Ecosystem: an Overview in Biological Nitrogen Fixation and Sustainability of Tropical Agriculture, International Institute of Tropical Agriculture (IITA) and African Association for Biological Nitrogen Fixation (AABNF)

Gardner, FP, Pearce, RB, \& Mitchell, RL, 1991, Penerjemah Herawati dan Susilo, Fisiologi Tanaman Budidaya, Universitas Indonesia Press, Jakarta

Hanafiah, KA, 2010, Rancangan Percobaan Teori dan Aplikasi, Edisi ke-3, PT. Rajagrafindo Persada, Jakarta

Harjadi, SS, 1991, Pengantar Agronomi, Penerbit PT. Gramedia, Jakarta

Huda, MK, 2013, Pembuatan Pupuk Organik Cair dari Urin Kelinci dengan Aditif Tetes Tebu (Molases) Metode Fermentasi, Skripsi, Universitas Negeri Semarang, Semarang

Jainurti, VE, 2016, Pengaruh Penambahan Tetes Tebu (Molase) pada Fermentasi Urin Sapi terhadap Pertumbuhan Bayam Merah (Amaranthus tricolor L.), Skripsi, Universitas Sanata Dharma, Yogyakarta

Jumrawati, 2008, Efektifitas Inokulasi Rhizobium sp Terhadap Pertumbuhan dan Hasil Tanaman Kedelai pada Tanah Jenuh Air, Dinas Pertanian Provinsi Sulawesi Tengah 
Kurniadinata, F, 2008, Pemamfaatan Feses dan Urin Sapi sebagai Pupuk Organik dalam Perkebunan Kelapa Sawit (Elaeis guinensis Jacq.), Skripsi, Universitas Mulawarman, Samarinda

Kurniawan, E, Ginting, Z \& Nurjannah, P, 2017, Pemanfaatan Urin Kambing pada Pembuatan Pupuk Organik Cair terhadap Kualitas Unsur Hara Makro (NPK), Seminar Nasional Sains dan Teknologi, Universitas Muhammadiyah, Jakarta

Kester, DE, 1981, Plant Scince: Growth, Development and Utilization of Cultivated Plants, First Edition, Prentice Hall, New York

Central Kalimantan Peatlands Project (CKPP), 2008, Tanya dan Jawab Sputar Gambut di Asia Tenggara, Khususnya di Indonesia, Universitas Palangka Raya (UPR), Kalimantan Tengah

Lingga, P, 2010, Petunjuk Penggunaan Pupuk, Penerbit Penebar Swadaya, Jakarta

Madigan, TM, Martinko, MJ \& Parker, J, 2002, Brock Biology of Microoganisms, 10th edition, Person Education Inc, USA

Masluki, Mutmainnah, Naim, M \& Thamrin, NT, 2017, 'Pengaruh Pertumbuhan Tanaman terhadap Rhizobacteria (PGPR) dan Pupuk Organik Cair pada Pertumbuhan Bayam (Amaranthus spp) dan Cabai (Capsicum annum) pada Fase Vegetatif', Prosiding Seminar Hasil Program Pengembangan Diri 2017 Bidang Pertanian, Konferensi Internasional Alam dan Ilmu Sosial, Universitas Cokrominoto Palopo, Makassar, hal. 28-219

Mulyadi, A, 2012, Pengaruh Pemberian Legin, Pupuk NPK (15:15:15) dan Urea pada Tanah Gambut Terhadap Kandungan N,P Total Pucuk dan Bintil Akar Kedelai (Glycine max (L) Merr.), Kaunia, vol. 8, no. 1, hal. 21-29

Nur, T, Noor, RA \& Elma, M, 2016, Pembuatan Pupuk Organik Cair dari Sampah Organik Rumah Tangga dengan Penambahan Bioaktivator EM4, Konversi, vol. 5, no. 2, hal. 11

Permentan, 2009, Peraturan Menteri Pertanian, No.28/SR.130/2009

Pranata, AS, 2010, Pupuk Organik Cair Aplikasi dan Manfaatnya, Penerbit Agromedia Pustaka, Jakarta

Prawiranata, W, Haran, S \& Tjondronegoro, P, 1981, Dasar-Dasar Fisiologi Tumbuhan, Departemen Botani, Fakultas Pertanian, Institut Pertanian Bogor, Bogor
Purwanti, S, 2011, Pertumbuhan dan Hasil Benih Kedelai Hitam Tumpang Sari Barisan dengan Jagung Manis, Skripsi, Unversitas Gadjah Mada, Yogyakarta

Rahman, AA, Barus, A \& Sipayung, R, 2017, Respon Pertumbuhan dan Produksi Tanaman Kedelai terhadap Pemberian Pupuk Organik Cair dan Mulsa, Jurnal Agroekoteknologi, vol. 5, no. 1, hal. 85

Rangkuti, JPN, Mukarlina \& Rahmawati, 2017, Pertumbuhan Bayam Merah (Amaranthus tricolor L.) yang Diberi Pupuk Kompos Kotoran Kambing dengan Dekomposer Trichoderma harzianum, Protobiont, vol. 6, no. 3, hal. 18-25

Rizki, K, Rasyad, A \& Murniati, 2014, Pengaruh Pemberian Urin Sapi yang Difermentasi Terhadap Pertumbuhan dan Poduksi Tanaman Sawi Hijau (Brassica rafa), Jom Faperta, vol. 1, no. 2 , hal. 3

Salisbury, FB \& CW, Ross, 1995, Fisiologi Tumbuhan, Terjemahan dari Plant Physiology, Penerjemah: Lukman, DR dan Sumaryono, Institut Teknologi Bandung, Bandung

Sarah, Rahmatan, H, \& Supriyatno 2016, Pengaruh Pemberian Berbagai Konsentrasi Urin Kambing yang Difermentasi terhadap Pertumbuhan Vegetatif Lada (Piper nigrum L.), Jurnal Ilmiah Mahasiswa Pendidikan Biologi, vol. 1, no. 1, hal. 1- 9

Simamora, Suhut \& Salundik, 2006, Meningkatkan Kualitas Kompos, Penerbit Agromedia Pustaka, Jakarta

Sudaryanto, T \& Swastika, DKS, 2007, Ekonomi Kedelai di Indonesia, Pusat Penelitian dan Pengembangan Tanaman Pangan, Badan Penelitian dan Pengembangan Pertanian, Bogor

Sundari, E, Sari, E \& Rinaldo, R, 2012, Pembuatan Pupuk Organik Cair Menggunakan Bioaktivator Biosca dan EM4, Prosiding STNK Topi, Fakultas Teknologi Industri, Universitas Bung Hatta, Jakarta

Sutedjo, MM, 2002, Pupuk dan Cara Pemupukan, Rineka Cipta, Jakarta

Sutedjo, MM, 2008, Pupuk dan Cara Pemupukan, Rineka Cipta, Jakarta

Suwahyono, U, 2011, Petunjuk Praktis Penggunaan Pupuk Organik Secara Efektif dan Efisien, Penebar Swadaya, Jakarta 
Swastika, DK, Nuryanti, SS \& Sawit, MH, 2007, Kedudukan Indonesia dalam Perdagangan Internasional Kedelai, dalam Sumarno, Suyamto, A, Widjono, Hermanto \& H, Kasim, 2007, Kedelai, Pusat Penelitian dan Pengembangan Tanaman Pangan, Badan Penelitian dan Pengembangan Pertanian, Bogor

Tamba, H, Irmansyah, T \& Hasanah, Y, 2017, Respon Pertumbuhan dan Produksi Kedelai (Glycine max (L.) Merrill) terhadap Aplikasi Pupuk Kandang Sapi dan Pupuk Organik Cair, Jurnal Agroekoteknologi, vol. 5, no. 2, hal. 307-314

Tampubolon, E, 2012, Pemanfaatan Limbah Ternak Sebagai Pupuk Cair Organik untuk Meningkatkan Pertumbuhan dan Produksi Selada (Lactuca sativa var. crispa), Skripsi, Institut Pertanian Bogor, Bogor
Tiwery, R, 2014, Pengaruh Penggunaan air kelapa (Cocos nucifera) terhadap Pertumbuhan Tanaman Sawi (Brassica juncea L.), Jurnal Biopendix, vol. 1, no. 1, hal. 1-9

Widodo, R, 2010, Pengaruh Konsentrasi Pupuk Organik Cair dan Jarak Tanam terhadap Pertumbuhan dan Hasil Kedelai Hitam (Glycine soja (L.) Sieb and Suc.), Skripsi, Universitas Sebelas Maret, Surakarta

Wijaya, K, 2010, Pengaruh Konsentrasi dan Frekuensi Pemberian Pupuk Organik Cair Hasil Perombakan Anaerob Limbah Makanan terhadap Pertumbuhan Tanaman Sawi (Brassica juncea L.), Skripsi, Universitas Sebelas Maret, Surakarta

Winarsi, H, 2010, Protein Kedelai dan Kecambah Manfaatnya Bagi Kesehatan, Penerbit Kanisius, Yogyakarta. 